\title{
DAMPAK PSIKOLOGIS PADA MAHASISWA BARU TERHADAP PEMBELAJARAN DARING DI MASA PANDEMI COVID-19
}

\author{
Lidya Wati Putri
}

\author{
Mahasiswa S1 Program Studi Psikologi, Fakultas Kedokteran, Universitas Lambung \\ Mangkurat \\ Jalan Jenderal A. Yani Km. 36,00 Banjarbaru Kalimantan Selatan, 70714, Indonesia \\ Email : watiputrilidya@gmail.com;2010914320015@mhs.ulm.ac.id
}

\begin{abstract}
Abstrak
Artikel ini bertujuan untuk mengetahui dampak psikologis pada mahasiswa baru mengenai pembelajaran secara daring di masa pandemic covid-19 ini. Cara yang digunakan adalah dengan literatur melalui artikel - artikel ataupun jurnal yang didapatkan di google scholar serta melalui pengalaman pribadi yang bersangkutan. Berdasarkan kajian literatur dan pengalaman pribadi yang bersangkutan, metode pembelajaran secara daring kuranglah efektif. Karena lebih banyak kemudharatannya daripada kemaslahatannya. Dan apabila ini dilakukan secara terus menerus dalam jangka waktu yang sangat panjang, mungkin banyak mahasiswa yang kecewa bahkan stres ringan. Sebab lebih efektif dan efisien pembelajaran secara tatap muka, karena mahasiswa dapat berinteraksi scara langsung dengan para dosen yang menyampaikan suatu ilmu pengetahuan. Walaupun di kampus Universitas Lambung Mangkurat metode pembelajaran secara daring difasilitasi dengan aplikasi Zoom Meeting, Google Classroom, Google Meeting, dan E-learning. Hal ini banyak menyebabkan dampak psikologis terhadap mahasiswa baru, karena metode pembelajaran ini kurang ampuh. Hingga sebagian besar mahasiswa sulit memahami ilmu yang disampaikan para dosen, terlebih para mahasiswa ini memiliki julukan sebagai "MABA" dan biasanya maba tidak banyak mengetahui informasi sehingga perlu penyampaian dari para dosen secara benar dan harus tepat sasaran.
\end{abstract}

Kata Kunci : Dampak psikologis, pembelajaran daring

\begin{abstract}
Abstact
This article aims to determine the psychological impact on new students regarding online learning during the Covid-19 pandemic. The method used is literature through articles or journals found on Google Scholar and through the personal experience concerned. Based on
\end{abstract}


the literature review and personal experience concerned, online learning methods are less effective. Because there is more harm than good. And if this is done continuously for a very long period of time, maybe many students will be disappointed and even have mild stress. Because it is more effective and efficient face-to-face learning, because students can interact directly with lecturers who convey knowledge. Even though on the campus of the University of Lambung Mangkurat online learning methods are facilitated by the Zoom Meeting application, Google Classroom, Google Meeting, and E-learning. This causes a lot of psychological impact on new students, because this learning method is less effective. So that most students find it difficult to understand the knowledge conveyed by the lecturers, especially these students have the nickname "MABA" and usually new students do not know much information so it is necessary to convey the lecturers correctly and it must be right on target.

Keywords : Psychological impact, online learning.

PENDAHULUAN

Pada mata kuliah Filsafat Umum di Program Studi Psikologi, Fakultas Kedokteran, Universitas Lambung Mangkurat kali ini, saya diberi kesempatan untuk dapat membuat sebuah artikel dengan tema yang bebas. Seperti yang dikatakan pada buku yang berjudul 'Menulis Di Kala Badai Covid-19' bahwa mahasiswa psikologi yang bakalan menjadi seorang calon psikolog yang memiliki tugas untuk meminta orang yang bermasalah secara psikologis dengan pikiran dan perasaannya agar klien dapat mengungkapkan masalah dan mengeluarkan semua unek - unek, bahkan mengungkapkan apa yang tertulis di memori seorang klien. Lalu, cara agar menyimpan secara baik adalah pasti dengan cara menulis [1].
Dan dengan adanya kegiatan menulis, akan menimbulkan suatu kebaikan bukan untuk keburukan. Seperti pada makalah 'Menualis di Era Covid-19' yang diciptakan oleh Prof. Ersis Warmansyah Abbas bahwa menulis hal - hal baik, menulis hal - hal yang bermanfaat, menulis perihal kebaikan, bukan untuk diri kita sendiri, tetapi untuk orang yang menjadi pembaca tulisan kita nanti [2]. Karena menulis pada saat pandemi seperti ini merupakan kegiatan yang sangat bermanfaat dan berfaedah. Walupun dengan adanya pandemic yang membuat kita di rumah saja, jangan sampai menghalangi kita dalam berkarya.

Pada awalnya saya mengalami kesulitan dalam menulis, karena jujur saya belum pernah melakukan kegiatan ini sama sekali. Akan tetapi setelah saya telaah 
melalui literatur - literatur seperti buku, jurnal, artikel, ataupun bahan bacaan lainnya. Saya mendapatkan tema yang akan saya angkat yaitu mengenai pengalaman pribadi saya sendiri. Seperti yang dikatakan Prof. Ersis Warmansyah Abbas bahwa menulis berarti memproses informasi atau pengalaman di otak.Dan kelancaran kita dalam menulis itu tergantung seberapa mantap informasi yang ditulis di otak kita [3]. Untuk mendapatkan informasi tersebut, tentu kita harus banyak membaca terlebih dahulu. Seperti yang dikatakan Prof. Ersis Warmansyah Abbas bahwa sepanjang kehidupan kita, di setiap aktivitas sehari hari, dapat dipastikan bahwa sesungguhnya kita 'membaca' dan 'menulis'. Membaca dalam artian kita memindai objek melalui pancaindra, lalu kita mengolah informasinya di dalam otak. Bahkan, ketika pancaindra kita bekerja, disengaja atau

\section{HASIL DAN PEMBAHASAN}

Covid-19 atau bisa disebut dengan corona virus, pertama kali ditemukan di Tiongkok pada bulan Desember tahun 2019. Virus corona mulai menyebar dan menyerang beberapa negara di awal tahun 2020, lalu masuk ke negara kita tercinta pada bulan Maret tahun 2020. Pada tanggal 11 Maret 2020 WHO menetapkan bahwa wabah virus ini sebagai pandemi bersifat tidak, bahkan sambal lalu saja, misalnya saja hanya sekadar lintasan tentang suatu yang ada di pikiran, maka proses membaca itu terjadi [4].

$$
\text { Proses menulis akan terasa }
$$
mengasyikan apabila kita mengikuti saran dari Prof. Ersis Warmansyah Abbas. Apa kata beliau? Beliau berpendapat bahwa menulis itu dipolakan dalam peta pikiran dan lakukan sebagai hal yang menyenangkan untuk menuju menulis yang mengasyikan [5]. Jadi saya pun memutuskan untuk mengangkat artikel yang bertemakan berdasarkan pengalaman pribadi saya sendiri dan melalui beberapa kajian literatur, yaitu 'dampak psikologis pada mahasiswa baru prodi psikologi terhadap pembelajaran daring di masa pandemi covid-19'.

global [6]. Pandemi covid-19 merupakan suatu kondisi dimana virus yang sudah mewabah secara luas ke seluruh dunia. Virus ini menyerang sistem pernafasan pada manusia. Masa pandemi covid-19 sudah berjalan kurang lebih selama 9 bulan. Sehingga karena hal inilah banyak mendorong perubahan secara drastis terhadap pendidikan di Indonesia. Demi meminimalisir penyebaran virus ini pemerintah mengambil tindakan dengan menciptakan kebijakan berupa segala 
kegiatan yang menyebabkan berkumpulnya banyak orang ditiadakan dan diganti dengan melakukannya secara online atau di rumah saja. Sehingga sistem pendidikan pun mau tidak mau harus dilaksanakan secara daring. Karena bagaimanapun kondisinya pendidikan sangat penting diberikan kepada seluruh pelajar di Indonesia walaupun terbatas ruang dan jarak yang hanya bisa dilakukan melalui teknologi zaman sekarang.

Pembelajaran daring ini dilakukan di rumah masing - masing dengan memanfaatkan berbagai macam aplikasi yang telah disediakan seperti Zoom Meeting, Google Meet, Google Class Room, dan E-learning. Pembelajaran daring dilaksanakan seefektif mungkin agar menciptakan kesejahteraan bersama. Namun bagaimanapun telah diusahakan, tetap saja terdapat kendala dalam metode pembelajaran ini. Sebab tak bisa dipungkiri, sebagian besar mahasiswa tidak berada di tempat yang mudah untuk mendapatkan sinyal. Bisa saja mahasiswa tersebut berada di pedalaman yang susah listrik bahkan susah mengakses sinyal internet. Tak hanya itu, kebanyakan mahasiswa mengalami dampak psikologis seperti stres sebab metode pembelajaran seperti ini membuat yang bersangkutan sulit untuk memahami ilmu yang disampaikan oleh para dosen.
Terlebih terhadap anak broken home, karena pada umumnya anak broken home jarang sekali mendapatkan perhatian orang - orang di rumahnya, ditambah lagi pembelajaran daring ini yang membuat para dosen tidak dapat berinteraksi langsung dengan mahasiswanya. Jadi menurut saya pembelajaran daring seperti ini membuat beberapa orang semakin tertekan. Apalagi pada mahasiswa baru yang tidak mempunyai teman satu daerah. Contohnya seperti saya yang benar - benar sangat kesulitan dengan kondisi seperti ini. Dengan adanya teman yang sama satu daerah, saya menjadi lebih mudah apabila ada suatu tugas yang perlu dikerjakan dan dikompromikan secara bersama. Hal ini membuat saya melakukan apa - apa secara mandiri. Tapi untungnya, saya masih bisa menanyakan hal - hal yang kurang dimengerti melalui chat, telepon, ataupun video call via whatsapp.

Tetapi ini semua dilakukan dengan tujuan agar dapat meminimalisir dan mengurangi penyebaran virus covid-19. Dengan dilaksanakannya semua kegiatan secara di rumah saja, tidak boleh menghambat kreativitas kita dalam berkarya. Terlebih untuk mahasiswa baru yang suka menulis. Ini merupakan kesempatan emas yang sangat berharga, karena kebanyakannya lembaga - lembaga mengadakan event dan perlombaan karya 
tulis ilmiah secara online. Hal ini membuat orang semakin rajin dan giat untuk menulis.

Menurut sebagian orang kegiatan menulis itu susah dan sulit, memang betul dan tidak dapat dipungkiri karena saya sendiri mengalaminya. Karena dalam proses menulis, kita memerlukan pikiran yang terbuka dan wawasan yang luas. Akan tetapi menurut pendapat Prof. Ersis Warmansyah Abbas ini tidaklah sesulit yang dibayangkan dan mudah dilakukan. Karena menurut beliau, setiap orang menulis pada helaan nafasnya dimana setiap saat kita melihat, mendengar, mencium, mengecap, dan merasakan sesuatu melalui pancaindra. Yang mana raupan panca indra yang telah didapatnya dituliskannya dan disimpannya di dalam otak kita setiap saat dan terus berlangsung selama kita hidup. Atau bisa dikatakan dengan 'orang telah menulis di dalam otaknya' [7].

Seperti yang saya alami saat ini, kami diberikan kesempatan untuk menulis bebas tetapi tetap mengikuti keilmiahan. Dengan ini saya pun memberanikan diri untuk menoba dan terus mencoba tanpa memperhatikan hasilnya nanti. Benar ataupun salah itu urusan belakangan, yang paling terpenting saya telah berani untuk melakukannya dan menikmati masa prosesnya. Semoga pandemi ini segera berakhir dan para mahasiswa baru dapat langsung turun ke kampus barunya. Karena menurut saya, metode pembelajaran seperti ini kebanyakan kendalanya. Tidak hanya kendala secara eksternal tetapi internal pun juga. Banyak sekali para mahasiswa baru yang kecewa terhadap kondisi sekarang ini. Sebab mereka tidak dapat bertemu secara langsung dengan para dosen, kakak tingkat, dan teman - teman barunya. Yang mana seharusnya awal dari perkualiahan harus disambut dengan kegembiraan, tetapi malah disambut dengan kekecewaan dan kesedihan.

Pembelajaran daring seperti ini memberikan dampak psikologis terhadap mahasiswa baru, terlebih pada diri saya sendiri. Saya sempat merasakan stres ringan, namun lambat laun saya mulai mengadaptasinya. Adaptasi sama halnya dengan penyesuaian diri. Penyesuaian diri merupakan proses yang meliputi respon mental dan perilaku yang merupakan usaha individu untuk mengatasi dan menguasai kebutuhan - kebutuhan dalam diri, ketegangan - ketegangan, frustasi dan konflik - konflik agar terdapat keselarasan antara tuntutan dalam diri dengan tuntutan yang terjadi di lingkungan sekitar. (Sarwono, 1992) [8].

Mungkin tidak semua mahasiswa baru mengalami dampak psikologis terhadap pembelajaran secara daring ini. Sebab respon setiap individu pada tugas 
perkembangan serta tuntutan pada masa ini berbeda - beda, tidak semua individu mampu mengatasi tantangan - tantangan pada tahap ini. Individu yang mempersiapkan dirinya dengan baik dalam perubahan ini, maka individu tersebut akan melewatinya secara siap untuk menjadi individu yang dewasa. Akan tetapi sebagian individu yang lainnya akan merasa periode ini adalah masa yang sulit dan penuh kegelisahan [9]. Dalam hal ini menimbulkan respon - respon terhadap stres dengan cara mengurangi ancaman dan efeknya, termasuk hal yang dilakukan, dirasakan atau dipikirkan seseorang dalam rangka menguasai, menghadapi, ataupun mengurangi efek - efek negatif dari situasi - situasi yang penuh tekanan bagi seseorang yang bersangkutan [10]. Karena semua orang yakin bahwa pandemi ini akan berakhir, jadi para mahasiswa baru akan menilai bahwa keadaan akan segera menjadi lebih baik. Dan kita seharusnya banyak berdoa serta selalu berpikiran postitif, lalu biarkanlah perasaan sedih atau kecewa itu muncul apabila kita merasa tidak kuat di saat tidak mampu dalam menghadapi masalah ini akan tetapi kita tetap harus bisa mengontrol emosi [10].

Pembelajaran daring seperti ini mengajarkan kita sebagai mahasiswa baru agar lebih berinisiatif lagi untuk belajar secara mandiri di rumah. Karena mahasiswa dituntut untuk bisa belajar dan mengerjakan tugas secara mandiri. Para dosen hanyalah perantara untuk menyampaikan suatu ilmu, dan kita sebagai mahasiswa lah yang harus menggali lebih dalam lagi ilmu yang telah diberikan tersebut. Di masa pandemi seperti ini, hanya diri kita lah yang dapat menentukan arah dan tujuan kita dalam belajar, sebab para dosen hanya dapat mengawasi kita secara online dan itu terhalang oleh ruang dan jarak. Sehingga seringkali mahasiswa baru belajar jika mendapati pelajaran yang menarik dan jika sedang tidak ada hal penting yang harus dilakukan. Lalu, banyak juga mahasiswa yang menganut sistem musiman dalam belajar, menunda untuk mengerjakan tugas karena belum sampai batas waktu yang telah ditentukan untuk mengumpulkan hingga sampai akhirnya batas waktu tersebut tiba di ambang pintu [11].

\section{METODE}

Dalam mencari artikel saya menggunakan web Google Scholar, setelah itu saya menggunakan kata kunci yang bersangkutan dengan tema yang saya angkat. Saat saya menggunakan kata kunci tersebut, saya menemukan sekitar 2.470 bahan bacaan baik berupa jurnal ataupun artikel. Tetapi yang saya ambil hanya ada 11 jurnal yang berasal dari kampus saya 
sendiri. Setelah saya mendapatkan referensi bacaan, saya pun menganalisisnya lalu membahasnya di artikel saya dari beberapa kalimat yang berasal dari referensi yang telah saya baca.

\section{KESIMPULAN}

Sejak bulan Maret tahun 2020 lalu hingga saat ini pandemi virus Covid-19 masih menyerang di dunia, termasuk di Indonesia. Covid-19 atau biasa disebut virus corona adalah wabah penyakit yang tempat lahirnya berada di Tiongkok dan penyebarannya berjalan secepat kilat ke seluruh dunia. Dengan masuknya virus ini ke Indonesia, membuat seluruh kegiatan yang ada berjalan tidak sebagaimana mestinya. Banyak kerugian yang muncul di berbagai bidang, seperti bidang ekonomi dan bidang pendidikan. Karena virus inilah semua metode pembelajaran di Indonesia mengalami perubahan. Yang mana perubahan ini sangat meresahkan seluruh pelajar di Indonesia, sebab mereka masih belum bisa membiasakan diri dan beradaptasi dengan keadaan yang terus berlangsung ini. Yang pada awalnya model pembelajaran dilakukan secara tatap muka, kini berubah menjadi pembelajaran secara daring atau online dengan menggunakan kecanggihan teknologi zaman sekarang. Tidak bisa dipungkiri tak hanya pelajar
SMP, SMA dan mahasiswa Perguruan Tinggi yang melakukan pembelajaran seperti ini, bahkan anak TK dan SD pun juga ikut melaksanakannya.

$\begin{array}{ccc}\text { Pembelajaran } & \text { secara daring } & \text { ini } \\ \text { memiliki } & \text { kemaslahatan } & \text { dan }\end{array}$
kemudharatannya. Sisi baiknya, saya sebagai mahasiswa baru lebih banyak memiliki waktu bersama keluarga sebab belum waktu yang tepat untuk merantau. Sedangkan sisi buruknya menurut saya lebih banyak sebab pembelajaran seperti ini memerlukan banyak biaya untuk membeli kuota. Lalu apabila adanya kendala jaringan, membuat suara dan gambar atau videonya menjadi putus - putus sehingga ada beberapa materi yang tidak dapat saya dengar lalu akhirnya tertinggal. Selanjutnya, hal ini sangat membuat saya tertekan, sebab yang pada awalnya saya sudah terbiasa pembelajaran secara tatap muka, kini harus menyesuaikan diri dengan model pembelajaran seperti ini, yang mana menurut pengalaman saya, suatu ilmu apabila disampaikan secara tatap muka langsung saja bisa sulit untuk dipahami, apalagi kalau cuman secara online yang hanya ditatap melalui layar handphone ataupun laptop. Tatkala keadaan seperti ini membuat saya tertekan yang berdampak pada psikologis saya. Tetapi saya yakin suatu saat pasti keadaan akan kembali seperti semula. 


\section{DAFTAR PUSTAKA}

[1] Abbas, E. W., \& Erlyani, N. (2020).

Menulis di Kala Badai Covid-19.

[2] WARMANSYAH ABBAS, E. R. S. I.

S. (2020). Menulis di Era Covid-19: Memanage Trauma Psikologis

Menghindari Psikosomatis. Menulis di Era Covid-19: Memanage Trauma Psikologis Menghindari Psikosomatis.

[3] Abbas, E. W. (2020). Menulis di Otak dan Menuliskan Tulisan di Otak.

[4] Abbas, E. W. (2015). Menulis Menuliskan Diri.

[5] Abbas, E. W. (2015). Menulis Mengasyikkan.

[6] Rahman, T. (2020). PEMBELAJARAN

DARING DI ERA COVID-19.

[7] Abbas, E. W. (2020). Menulis Mudah, Menulis Ala Ersis Writing Theory.

[8] Putri, D. U. M., Anward, H. H., \& Erlyani, N. (2017). Peranan Penyesuaian Diri terhadap Stres Akibat Kemacetan pada Mahasiswa Fakultas Kedokteran Universitas Lambung Mangkurat Banjarmasin. Jurnal Ecopsy, 3(2).

[9] Afnan, A., Fauzia, R., \& Tanau, M. U. (2020). HUBUNGAN EFIKASI DIRI DENGAN STRESS PADA MAHASISWA YANG BERADA DALAM FASE
QUARTER LIFE CRISIS. Jurnal Kognisia: Jurnal Mahasiswa Psikologi Online, 3(1), 23-29.

[10] Rachmah, D. N. (2016). Self Efficacy, Coping Stress dan Prestasi Akademik Mahasiswa Program Studi Psikologi Fakultas Kedokteran Universitas Lambung Mangkurat. Jurnal Ecopsy, 1(1).

[11] Amini, M., Mayangsari, M. D., \& Zwagery, R. V. (2020). Hubungan antara Kemandirian Belajar dengan Komitmen Tugas pada Mahasiswa Program Studi Psikologi. Jurnal Kognisia: Jurnal Mahasiswa Psikologi Online,2(2), 149152. 